\title{
Study of Relation of Lactate Dehydrogenase Levels with Severity of Preeclampsia and its foetal Outcome
}

\author{
Unmesh Suresh Santpur' ${ }^{1}$, Madhavi U Santpur², Sushma ${ }^{3}$ \\ ${ }^{1}$ Associate Professor in Obstetrics and Gynaecology, Maharishi Markandeshwar Institute Of Medical Sciences and Research \\ Mullana, Haryana , India \\ ${ }^{2}$ Associate Professor in Anaesthesia, Maharishi Markandeshwar Institute of Medical Sciences and Research, Mullana, Haryana, India \\ ${ }^{3}$ Senior Resident in Obstetrics and Gynaecology
}

\begin{abstract}
Background: Pre eclampsia is a multisystem disorder characterized by vascular endothelial dysfunction. Elevated levels of LDH indicates cellular damage and can be used as a biochemical marker to reflect complications and fetal outcome. Aim: To analyse the severity of preeclampsia and evaluate the outcome of baby by raised LDH levels. Material and methods: 100 patients with high blood pressure after 28 weeks of gestational age were included. The diagnosis of severe pre-eclampsia was made when a diastolic blood pressure was measured $\geq 110 \mathrm{mmHg}$ on two or more occasions, or $\geq 120 \mathrm{mmHg}$ on one or more occasions, in the context of significant proteinuria $(\geq 300 \mathrm{mg} / 24$ hours, or persistent $\geq 1+$ on dipstick). Serum LDH level was done twice weekly .A baseline ultrasound was performed. Reversed end-diastolic flow was an indication for delivery. Observation and results: In severe preeclampsia group 40\% patients had LDH levels $>800$ IU/L 50\% of babies had low birth weight with maternal serum LDH levels $<600$ IU/L.66 \%of babies had low birth weight with maternal serum LDH levels > $600 \mathrm{IU} / \mathrm{L}$. Conclusion : Raised LDH levels can predict the occurrence of maternal and neonatal complications.
\end{abstract}

Keywords: preeclampsia, LDH levels, maternal, neonatal complications

\section{Introduction}

Hypertensive disease in pregnancy is one of the main reasons of maternal, fetal and neonatal morbidity and mortality. As preeclampsia is a multisystem disorder with different clinical characteristics, prevention, diagnosis and therapy of this disease requires close inter-disciplinary cooperation ${ }^{[1]}$ Preeclampsia affects about 5 to $10 \%$ of all pregnancies. ${ }^{[2]}$ The etiology of preeclampsia is unknown but thought to be related to hypoxia in the placenta $^{[3]}$. Preeclampsia is defined as hypertension associated with proteinuria, greater than $0.3 \mathrm{~g} / \mathrm{l}$ in a $24 \mathrm{hr}$ urine collection or $1+$ by qualitative urine examination , after 20 weeks of gestation ${ }^{[4]}$ Mild preeclampsia is defined as diastolic blood pressure less than $110 \mathrm{mmHg}$. Severe preeclampsia is defined as systolic blood pressure of 160 $\mathrm{mmHg}$ or more and diastolic blood pressure of $110 \mathrm{mmHg}$ or more. ${ }^{[5]}$ Preeclampsia and eclampsia becomes apparent at the last stage in the pregnancy usually in third trimester. ${ }^{\text {[6) }}$ Lactate dehydrogenase(LDH) is most often measured to evaluate the presence of tissue damage. Dysfunction of endothelial cells can contribute to inappropriate vasoconstriction and platelet aggregation which are early signs of atherosclerosis, hypertension and coronary vasospasm. Acute clinical symptoms that endanger the life of fetus in preeclampsia correlate with distinct activity of aspartate transaminase (AST) and lactate dehydrogenase (LDH). ${ }^{[7]} \mathrm{LDH}$ is useful biochemical marker that reflects the severity and occurrence of complications of preeclampsia. ${ }^{[8]}$ The present study was to evaluate the co relation of $\mathrm{LDH}$ level with severity of preeclampsia and fetal out come.
Aim

- To analyse the severity of preeclampsia by raised LDH levels

- To evaluate the outcome of fetus in case of preeclampsia with raised $\mathrm{LDH}$ levels.

Inclusion criteria

- Antenatal patients with high blood pressure (BP) recordings

- Patients with proteinuria>0.3gm per $24 \mathrm{hrs}$.

Exclusion criteria

- Patients with urinary tract infection

- Chronic hypertensives.

- Eclamptic patients.

- Patients with diabetes or any other medical and surgical disorders

- Multiple gestations

\section{Material and Methods}

The present clinical study was conducted after obtaining approval from institutional ethical committee. The present study was undertaken to evaluate the severity of preeclampsia and outcome of baby by raised LDH levels. All women presenting after 28 weeks of gestation, with high $\mathrm{BP}$ and with proteinuria $>0.3 \mathrm{gm}$ per $24 \mathrm{hrs}$ were hospitalized. The diagnosis of severe pre-eclampsia was made when a diastolic blood pressure was measured $\geq 110 \mathrm{mmHg}$ on two or more occasions, or $\geq 120 \mathrm{mmHg}$ on one or more occasions, in the context of significant proteinuria $(\geq 300$ $\mathrm{mg} / 24$ hours, or persistent $\geq 1+$ on dipstick). Gestational assessment was based on the best available evidence, using 


\section{International Journal of Science and Research (IJSR) \\ ISSN (Online): 2319-7064 \\ Index Copernicus Value (2015): 78.96 | Impact Factor (2015): 6.391}

ultrasound, symphysio - fundal height measurement and the menstrual history. On admission, patients were monitored as follows: Six-hourly cardiotocograph (CTG) recording of fetuses $\geq 28$ weeks of gestation. Fetal distress was defined as baseline variability less than 5 over 60 minutes, repeated late decelerations or both. Blood pressure was recorded at six hourly intervals. This frequency was increased to half-hourly if a diastolic blood pressure of $\geq 110 \mathrm{~mm} \mathrm{Hg}$, until control of the blood pressure had been achieved. When urine dipstick testing was inconclusive, a 24-hour collection of urine was done .Serum LDH level was done twice weekly .A baseline ultrasound was performed, to assess fetal weight and amniotic fluid volume, and to exclude the presence of fetal abnormalities or maternal ascites. Umbilical artery doppler was added if intrauterine growth retardation (IUGR) was suspected. The ultrasound was repeated every second week, to assess the growth. Reversed end-diastolic flow was an indication for delivery.

\section{Observations and Results}

Table 1: Distribution of Study Population $(\mathrm{n}=100)$

\begin{tabular}{|c|c|c|}
\hline Group & Frequency & Percentage \\
\hline Severe Preeclampsia & 34 & $34 \%$ \\
\hline Mild Preeclampsia & 33 & $33 \%$ \\
\hline With One High BP reading & 33 & $33 \%$ \\
\hline TOTAL & 100 & $100 \%$ \\
\hline
\end{tabular}

The study group was categorized according to the severity of preeclampsia as shown in TABLE $1.34 \%$ of cases had severe preeclampsia and $33 \%$ had mild preeclampsia or only one high BP reading.
Table 2: Distribution of Patients in Each Group According To LDH Levels

\begin{tabular}{|c|c|c|c|c|}
\hline Group & LDH <600 & $\begin{array}{c}\text { LDH 600- } \\
800\end{array}$ & $\begin{array}{c}\text { LDH } \\
>800\end{array}$ & TOTAL \\
\hline $\begin{array}{c}\text { Severe } \\
\text { Preeclampsia }\end{array}$ & $14(40 \%)$ & $6(20 \%)$ & $14(40 \%)$ & $34(100 \%)$ \\
\hline Mild Preeclampsia & $26(80 \%)$ & $7(20 \%)$ & $0(0 \%)$ & $33(100 \%)$ \\
\hline $\begin{array}{c}\text { With One High BP } \\
\text { Recording }\end{array}$ & $33(100 \%)$ & $0(0 \%)$ & $0(0 \%)$ & $33(100 \%)$ \\
\hline Total & $73(73 \%)$ & $13(13 \%)$ & $14(13 \%)$ & $100(100 \%)$ \\
\hline
\end{tabular}

As shown in TABLE 2, 40\% patients of severe preeclampsia group had LDH levels >800 whereas $0 \%$ patients in other two groups had LDH levels > than 800

Table 3

\begin{tabular}{|c|c|c|c|c|}
\hline LDH & $\begin{array}{c}\text { Low Birth } \\
\text { Weight }\end{array}$ & $\begin{array}{c}\text { Normal Birth } \\
\text { Weight }\end{array}$ & Total \\
\hline$<600 \mathrm{IU} / \mathrm{L}$ & No Percentage & $15(50 \%)$ & $15(50 \%)$ & $30(40 \%)$ \\
\hline$>600 \mathrm{IU} / \mathrm{L}$ & No Percentage & $29(66 \%)$ & $15(34 \%)$ & $44(60 \%)$ \\
\hline TOTAL & No Percentage & $44(60 \%)$ & $30(40 \%)$ & $74(100 \%)$ \\
\hline
\end{tabular}

Association between LDH Levels In Preeclampsia and Baby Weight $(n=100)$

As shown in table no 3,50\% of babies had low birth weight with maternal serum LDH levels <600 IU/L. $66 \%$ of babies had low birth weight with maternal serum LDH levels $>600$ IU/L

Table 4

\begin{tabular}{|c|c|c|c|c|c|c|}
\hline LDH & $\begin{array}{c}\text { Intrauterine Fetal } \\
\text { Demise }\end{array}$ & $\begin{array}{c}\text { Intrauterine } \\
\text { Growth Restriction }\end{array}$ & $\begin{array}{c}\text { NICU } \\
\text { Admission }\end{array}$ & NIL & Total \\
\hline$<600 \mathrm{IU} / \mathrm{L}$ & No. Percent & $0(0 \%)$ & $0(0 \%)$ & $0(0 \%)$ & $30(100 \%)$ & $3040 \%$ \\
\hline$>600 \mathrm{IU} / \mathrm{L}$ & No. Percent & $14.6(33.33 \%)$ & $14.6(33.33 \%)$ & $14.6(33.33 \%)$ & $0(0 \%)$ & $44(60 \%)$ \\
\hline TOTAL & No. Percent & $24.6(33.33 \%)$ & $24.6(33.33 \%)$ & $24.6(33.33 \%)$ & $30(100 \%)$ & $74(100 \%)$ \\
\hline
\end{tabular}

Association between LDH Levels in Preeclampsia and Neonatal Complications $(\mathrm{N}=100)$

Association between LDH levels in preeclampsia and neonatal complications $(n=100)$ is depicted in Table 4.Babies having maternal LDH levels $<600$ IU/L are showing no neonatal complications and babies having maternal LDH levels > $600 \mathrm{IU} / \mathrm{L}$ are showing $33.33 \%$ of IUFD, IUGR and NICU admissions .

Table 5

\begin{tabular}{|c|c|c|c|c|c|c|}
\hline GROUP & & IUFD & IUGR & NICU & NIL & TOTAL \\
\hline Severe Preeclampsia & No. Percent & $1(4 \%)$ & $1(4 \%)$ & $2(6 \%)$ & $30(86 \%)$ & $34(100 \%)$ \\
\hline Mild Pre-Eclampsia & No. Percent & $0(0 \%)$ & $0(0 \%)$ & $3(8 \%)$ & $30(92 \%)$ & $33(100 \%)$ \\
\hline With One High BP Recording & No. Percent & $0(0 \%)$ & $0(0 \%)$ & $0(0 \%)$ & $33(100 \%)$ & $33(100 \%)$ \\
\hline Total & No. Percent & $1(1 \%)$ & $1(1 \%)$ & $5(5 \%)$ & $93(93 \%)$ & $100(100 \%)$ \\
\hline
\end{tabular}

Association between three Groups and Neonatal Complications

Association between three groups and neonatal complications is shown in Table 5.

In severe pre eclampsia group there are $4 \%$ IUFD,4\%IUGR, $6 \%$ NICU admissions. In mild pre eclampsia there were no IUD, IUGR, $85 \%$ of NICU admissions and in group with one high BP recording there were no neonatal complications.

Table 6

\begin{tabular}{|c|c|c|c|c|}
\hline Group & & LSCS & Vaginal & Total \\
\hline $\begin{array}{c}\text { Severe Pre- } \\
\text { Eclampsia }\end{array}$ & No. Percent & $8(24 \%)$ & $26(76 \%)$ & $34(100 \%)$ \\
\hline $\begin{array}{c}\text { Mild Pre- } \\
\text { Eclampsia }\end{array}$ & No. Percent & $7(22 \%)$ & $26(78 \%)$ & $33(100 \%)$ \\
\hline $\begin{array}{c}\text { With One High } \\
\text { BP Recording }\end{array}$ & No. Percent & $3(10 \%)$ & $30(90 \%)$ & $33(100 \%)$ \\
\hline Total & No. Percent & $18(19 \%)$ & $82(81 \%)$ & $100(100 \%)$ \\
\hline
\end{tabular}

\section{Volume 6 Issue 7, July 2017 www.ijsr.net}




\section{International Journal of Science and Research (IJSR) \\ ISSN (Online): 2319-7064 \\ Index Copernicus Value (2015): 78.96 | Impact Factor (2015): 6.391}

As shown in table 6, in severe pre eclampsia $24 \%$ have undergone LSCS and in mild pre eclampsia $22 \%$, and in group with one high BP recording $10 \%$ have undergone LSCS.
Table 7: Association between LDH Level and Type of LSCS is Shown in Table 7

\begin{tabular}{|c|c|c|c|c|}
\hline $\begin{array}{c}\text { LDH } \\
\text { Levels }\end{array}$ & & $\begin{array}{c}\text { Emergency } \\
\text { LSCS }\end{array}$ & $\begin{array}{c}\text { Elective } \\
\text { LSCS }\end{array}$ & Total \\
\hline$<600$ & No. Percent & $3(20 \%)$ & $10(80 \%)$ & $13(33.3 \%)$ \\
\hline$>600$ & No. Percent & $10(40 \%)$ & $16(60 \%)$ & $26(66.6 \%)$ \\
\hline Total & No. Percent & $13(33.33 \%)$ & $26(66.66 \%)$ & $39(100 \%)$ \\
\hline
\end{tabular}

In patients with LDH levels <600 20\% have undergone emergency LSCS.

In patients with LDH levels >600 40\% have undergone emergency LSCS.

Table 8

\begin{tabular}{|l|l|l|l|l|l|l|}
\hline TYPE OF LSCS & & IUFD & IUGR & NICU & NIL & TOTAL \\
\hline Emergency LSCS & No Percent & $1(2.5 \%)$ & $1(2.5 \%)$ & $1(2.5 \%)$ & $10(25.6 \%)$ & $13(33.33 \%)$ \\
\hline Elective LSCS & No. Percent & $0(0 \%)$ & $0(0 \%)$ & $2(5.1 \%)$ & $24(61.4 \%)$ & $26(66.66 \%)$ \\
\hline Total & No. Percent & $1(2.5 \%)$ & $1(2.5 \%)$ & $3(7.6 \%)$ & $34(87 \%)$ & $39(100 \%)$ \\
\hline
\end{tabular}

Association between type of LSCS and Neonatal Complications $(\mathrm{N}=39)$ is Shown in Table 8

As shown in table 8

After emergency LSCS there were $2.5 \%$ of IUD, IUGR AND NICU admissions. After elective LSCS there were no IUD, IUGR, but $5.1 \%$ of NICU admissions.

Table 9

\begin{tabular}{|c|c|c|c|c|}
\hline & & $>34$ Weeks & $<34$ Weeks & Total \\
\hline Severe PE & No. Percent & $30(30 \%)$ & $4(4 \%)$ & $34(34 \%)$ \\
\hline Mild PE & No. Percent & $32(32 \%)$ & $1(1 \%)$ & $33(33 \%)$ \\
\hline $\begin{array}{l}\text { With One High } \\
\text { BP Recording }\end{array}$ & No. Percent & $33(33 \%)$ & $0(0 \%)$ & $33(33 \%)$ \\
\hline Total & & $95(95 \%)$ & $5(5 \%)$ & $100(100 \%)$ \\
\hline
\end{tabular}

Association between three Groups and Gestational Ages at Termination $(\mathrm{n}=100)$

Association between three groups and gestational ages at termination $(n=100)$ is shown in table 9 In severe pre eclampsia , 4\%of pregnancies were terminated before 34 weeks, and $1 \%$ in mild pre eclampsia and none in group with one high BP recording.

Table 10

\begin{tabular}{|c|c|c|c|c|}
\hline LDH Levels & & $<34$ Weeks & $>34$ Weeks & Total \\
\hline$<600$ & No. Percent & $0(0 \%)$ & $73(73 \%)$ & $73(73 \%)$ \\
\hline$>600$ & No. Percent & $5(5 \%)$ & $22(22 \%)$ & $27(27 \%)$ \\
\hline TOTAL & No. Percent & $5(5 \%)$ & $95(95 \%)$ & $100(100 \%)$ \\
\hline
\end{tabular}

Association between LDH Levels and Gestational Age of Termination $(\mathrm{N}=100)$

As shown in Table 10, in patients with LDH levels <600, $73 \%$ of pregnancies were terminated after 34 weeks and with $>600$ only $22 \%$ were terminated after 34 weeks.

\section{Discussion}

Pre eclampsia is an important disease of pregnancy with potentially severe consequences for mother and child. Its progression differs among patients. Severe preeclampsia can lead to grave complications like convulsions, HELLP SYNDROME, DIC, intracranial bleed, IUFD and even maternal mortality. Acute clinical symptoms that endanger the life of fetus in preeclampsia corelate with distinct activity of AST and LDH.

\section{Comparing LDH levels}

On analyzing the data in the study conducted byY. Umasatyasri ${ }^{[9]}$ et al, it was observed that there is significant rise in the LDH levels with increasing severity of the disease $(P<0.001-$ statistically significant $)$. In another study done by Qublan $\mathrm{HS}^{[8]}$, et al. they found that the mean LDH levels in normal controls was $299 \pm 79 \mathrm{IU} / \mathrm{l}$, in patients with mild preeclampsia was $348 \pm 76 \mathrm{IU} / 1$ and in patients with severe preeclampsia was $774 \pm 69.61 \mathrm{IU} / \mathrm{l}$. Thus, they demonstrated a significant association of serum LDH levels with severe preeclampsia. This outcome was in accordance with the present study.

\section{Mode of delivery:}

While studying the mode of delivery of the patients ,no significance was found in the 3 groups studied. In the severe preeclampsia group $92 \%$ patients with $\mathrm{LDH}>600 \mathrm{IU} / \mathrm{L}$ had undergone LSCS. No comparative study was available to study the mode of delivery.

\section{Baby Weight:}

According to the study by Y. Umasatyasri ${ }^{[9]}$ et al , there was reduction in the average weight of babies with higher level of LDH but not statistically significant ( $p=0.926$ ). In the present study, $50 \%$ of babies had low birth weight with maternal serum LDH levels <600 IU/L where as $66 \%$ of babies had low birth weight with maternal serum LDH levels > $600 \mathrm{IU} / \mathrm{L}$. This indicates increase in preterm deliveries in patients with higher LDH levels .The association of low birth weight of infants with increase in serum LDH levels was suggested by $\mathrm{He} S^{[10]}$, et al. in their study. This was in contrary to Qublan $\mathrm{HS}^{[8]}$, et al. who did not find any significant association.

According to Jaiswar $\mathrm{SP}^{[11]}$, et al study, there were significant low birth weight babies in women with higher LDH levels. $(P=0.019)$

\section{Volume 6 Issue 7, July 2017 www.ijsr.net}




\section{International Journal of Science and Research (IJSR) \\ ISSN (Online): 2319-7064 \\ Index Copernicus Value (2015): 78.96 | Impact Factor (2015): 6.391}

In our study it was found that $50 \%$ of women with severe preeclampsia had low birth weight babies. But there was no significant difference in the $\mathrm{LDH}$ levels of patients with small for gestational age infants. $60 \%$ of patients with $\mathrm{LDH}$ levels $>600 \mathrm{IU} / \mathrm{L}$ had low birth weight babies.

He S, Brennen $\mathrm{K}^{[10]}$ et al reported that pre eclamptic women with small for gestational age infants had higher LDH concentrations than those in the appropriate for gestational age group.

\section{Neonatal complications}

In the present study, neonatal complications like IUFD,IUGR, and NICU care were higher in the severe preeclampsia group. Qublan Hussein $S^{[8]}$ et al reported that perinatal mortality were increased in patients with LDH $>800$ IU/L compared with those who had lower levels. In the study by Y. Umasatyasri ${ }^{[9]}$ et al, there were 5 intrauterine deaths. In the women with LDH levels in the range of 600-800 IU/1 (24 cases), 12 cases had uneventful 3 had early neonatal death. In this group no still births and there were 3 intrauterine deaths. In the third group where LDH levels were markedly elevated (i.e., >800 IU/l) there were 11 cases out of which only 6 had uneventful outcome, whereas 2 had neonatal complications and 1 was early neonatal death.

\section{Association between three groups and gestational ages at termination}

In the present study in patients with LDH levels <600, 73\% of pregnancies were terminated after 34 weeks and with $>600$ only $22 \%$ were terminated after 34 weeks, whereas in the study of Y. Umasatyasri ${ }^{[9]}$ et al, the mean gestational age at the time of delivery was $37.60 \pm 2.76$ weeks in cases with LDH levels <600 IU/l. It was less in patients with LDH level in between 600 and $800 \mathrm{IU} / \mathrm{l}$, which was $36.71 \pm 2.96$ weeks and $36.27 \pm 2.69$ weeks in patients with $\mathrm{LDH}>800 \mathrm{IU} / 1$.

\section{Conclusion}

Raised LDH levels can predict the occurrence of maternal complications and therefore can be used as a laboratory based evidence of endothelial damage in preeclampsia.LDH can act as a single predictor or in conjunction with other predictors as a good parameter to detect the severity of preeclampsia and the occurrence of neonatal complications.

\section{References}

[1] Schmidt M, Fink D, Lang U, kimming R.[hypertensive diseases during pregnancy: an interdisciplinary challenge] Gynskol Geburtshilfiche Rundsch.2007;47:197-80.

[2] Schmidt M, Kimming R. [Pathophysiology of preeclampsia] Gynakol geburtshifliche Rundsch.2007;47(4):199-204

[3] Kay HH, Zhu S, Tsoi S. Hypoxia and lactate production in trophoblast cells. Placenta. 2007;28(8-9):854-60
[4] National High bloop pressure education programme: working group report on high blood pressure in pregnancy. Am J Obstetric Gynecology 183:51, 2000.

[5] American college of obstetricians and gynecologists: Diagnosis and management of preeclampsia and eclampsia. Practice Bulletin No.33, January 2002

[6] A Jaleel, A Baseer . Gamma glutamyl transferase(GGT) activity in pregnancy induced hypertension. Pakistan's MedSci 1997; 14(1):67-71.

[7] Malarewicz A, Gruszka O, Szymkiewicz J, Rogala J.[ the usefulness of routine laboratory tests in the evaluation of sudden threat of pregnant and fetus in preeclampsia] Ginekol pol.2006 apr;77(4):276-84

[8] H S Qublan, V Ammarin, O Batainesh, Z Alshraidesh, Y Tahat. I Awamleh, B Khreisat, B Nussair, $\mathrm{Z} O \mathrm{O}$ Amarin. Lactate dehydrogenase as a biochemical marker of adverse pregnancy outcome in severe Preeclampsia. Med Sci Monit. 2005;11(8):393-397.

[9] Y. Umasatyasri, I.Vani, P. Shamita. Role of LDH (Lactate dehydrogenase) in preeclampsia - eclampsia as a prognostic marker: An observational study. IAIM, 2015; 2(9): 88-93.

[10]He S, Bremme K, Kallner A, Blomback M. Increased concentrations of lactate dehydrogenase in pregnancy with preeclampsia: a predictor for the birth of small for gestational age infants. Gynecology Obstetric Invest. 1995;39(4):234-8.

[11] Jaiswar S.P., Gupta Amrit, Sachan Rekha, Natu S.N, Shaili Mohan. Lactic Dehydrogenase: A biochemical marker for preeclampsia-eclampsia. JOGI, 2011;61(6): 645-648. 